\title{
Comparative evaluation of chemical and functional properties of some lima bean varieties (Phaseolus Iunatus) consumed in Arondizuogu, Imo state, Nigeria
}

\author{
Obiakor- Okeke, P. N. \\ Faculty of Health Sciences, Department of Nutrition and Dietetics, Imo State University, PMB 2000, Owerri, Imo State Nigeria
}

\section{Email address:}

ngoziobiakor2001@yahoo.com

\section{To cite this article:}

Obiakor- Okeke, P. N.. Comparative Evaluation of Chemical and Functional Properties of Some Lima Bean Varieties (Phaseolus Lunatus) Consumed in Arondizuogu, Imo state, Nigeria. Journal of Food and Nutrition Sciences. Vol. 2, No. 4, 2014, pp. 168-172.

doi: $10.11648 /$ j.jfns.20140204.21

\begin{abstract}
Aim: A comparative assessment of chemical and functional properties of some varieties of lima bean consumed in Arondizuogu, Imo state were carried out. Methodology: Seven varieties of lima bean, identified on the basis of colour were purchased from a local market. One kilogram of each variety was cleaned, washed with tap water and milled into fine flours $(70 \mathrm{~mm}$ mesh screen). The flours were analyzed for proximate, minerals, anti nutrient, food toxicant, and functional properties using standard assay methods. Result: The protein content of the lima bean varieties ranged from 19.33 to $25.43 \%$. All the varieties had high and comparable values for ash and fibre (3.88 to $4.13 \%$ and 3.99 to $4.43 \%$ ) respectively. The fat content of all the varieties were low. The seven varieties had high and comparable carbohydrate level (65.60\% to $71.51 \%$ ) The zinc and iron values ranged from 28.88 to $33.06 \mathrm{mg}$ and 57.22 to $6.24 \mathrm{mg}$. The mottled brown, deep cream and mottled black varieties had highest iron content $(60.02,60.24$ and $60.22 \mathrm{mg}$ ), while the dark red variety had the highest zinc level $(33.06 \mathrm{mg})$ followed by the dark brown and black with zinc values of $(31.45$ and $31.44 \mathrm{mg}, \mathrm{j}$ respectively. The phosphorus and copper content of all the varieties were high and comparable (4.20 to $4.66 \mathrm{mg}$ and 4.38 to 4. $68 \mathrm{mg}$ ). The hydrogen cyanide levels of all the varieties were high (38.38 to $43.55 \mathrm{mg}$ ). The water absorption capacity, foam capacity and least gelation concentration were high in all the varieties (63.21 to 70.33, 12.08 to 13.18 and 14-16, respectively). Conclusion: Lima bean has a high nutrient profile despite the variety. It is rich in protein, ash, fiber, zinc, copper, iron, phosphorus and has a good functional attributes.
\end{abstract}

Keywords: Evaluation, Chemical, Functional, Properties, Lima Bean Varieties, Arondizuogu

\section{Introduction}

In Nigeria, a lot of under exploited plant food crops with promising nutritional potentials abound (I). Despite the large number of existing grain legumes, their consumption as staple foods have centered mainly on cowpea and groundnut. Several other locally available species like the lima bean, pigeon pea and jack bean, which have remarkable adaptation to tropical conditions, are less commonly used, Lima bean is a lesser known legume. This is because many communities are not aware of its nutritional potentials. Lima bean could easily be utilized as many food preparation. It is usually consumed in contribution with cereals such as rice, maize, sorghum etc or with plantain. It is a good source of protein, fibre, iron, zinc, potassium, and magnesium and B-complex vitamins
(2). It is imperative to investigate the positive attributes of this important food legume, mostly its nutrient contribution to the diet and also to provide useful information that could improve its utilization.

\section{Materials}

Table 1. Lima Bean Varieties

\begin{tabular}{ll}
\hline Lima Bean Varieties & Degree of Availability \\
\hline Black variety & Common \\
Dark brown variety & Seen sparingly \\
Mottled black variety & Rare \\
Dark red variety & Common \\
Golden brown variety & Seen sparingly \\
Deep cream variety & Rare \\
Mottled brown variety & Rare \\
\hline
\end{tabular}


The seven varieties of lima bean used for the study were bought from a local market in Arondizuogu from Imo State.

Lima Bean Varieties: The different varieties of lima bean and their degree of availability are shown in table 1.

Black and dark red varieties are commonly available because they are cultivated by a lot of people. The black variety produces a higher yield hence, it is more in the local market than the other varieties. The mottled black, deep cream and mottled brown are very rare. They are produced by few farmers only for their family consumption. The reason is that they produce low field, therefore a lot of farmers are not interested in cultivating them.

The golden brown and dark brown varieties are available but not as the black and dark red varieties. Their cultivation is not as wide as the dark red and black which are commonly available and consumed by a lot of people in the area.

\section{Methodology}

\subsection{Preparation of Sample}

The lima bean seeds were handpicked to remove the damaged seeds and contaminants. About $1 \mathrm{~kg}$ of each lima bean variety was separately washed with tap water, dried in a hot air oven (Gallenkamp. BS Ove , Model No.320) at $600^{\circ} \mathrm{C}$ for $3 \mathrm{~h}$ to $96 \%$ dry matter and milled into fine flours (70mm mesh screen) using a CT8 laboratory mill. The raw flour samples were packaged separately in polythene bags until analyzed.

\subsection{Chemical Analysis}

Proximate compositions of the samples were analyzed according to the method of A.O.A.C. (3) Residual moisture was determined by the hot air oven method as described by Polacchi (4).

The mineral $(\mathrm{Zn}, \mathrm{Cu}, \mathrm{Fe}, \mathrm{Mg}$ and $\mathrm{P})$ content of the samples were estimated by the method of Ranjiham and Gopal (5), after wet digestion with concentrated nitric and hydrochloric acids. Tannin was determined by the modified vanillin method of Price and Buttler (6). The method of latta and Eskin (7) was employed in phytate estimation. Trypsin inhibitor was determined by the method of
Harnmerstrand et al (8). The cyanide content of the samples were determined enzymatically using the method of cooke (9). The water absorption capacity was determined by the method, described by Odo and Ishiuwu (10). Oil absorption capacity, least gelation concentration and foam capacity where imated using the method of Onimawo and Akubor (11).

\subsection{Statistical Analysis}

Mean and standard deviation were calculated for the samples using the procedure of Obi (12).

\section{Results and Discussion}

\subsection{Proximate Composition}

The proximate composition of the lima bean samples are shown in table 2 below. The protein values ranged from 19.33 to $25.43 \%$. The deep cream variety (DCV) had the highest protein level $(25.43 \%)$, relative to other varieties. The mottled black had the lowest protein (19.33\%). The protein content of all the varieties were similar to those found in other legumes $(13,14$, and 15). The mottled brown, (MVRV), deep cream (DCV) and mottled black (MBKV), had lower and comparable fat values $(0.94,0.96$, and $0.98 \%$ ) as against other varieties. The black and dark brown varieties had the highest value (1.15 and 1.12 , percent respectively). The low fat content for all the varieties was not a surprise. This is because legumes store energy in form of carbohydrate and not fat. There were variations in the ash level. It ranged from 3.83 to $4.13 \%$. The MBRV had the highest ash value, followed by the BKV (4.13 and 4.12\%) respectively. This finding accords the reports of many workers on legumes $(16,17)$. All the varieties had comparable values for crude fibre. Lima bean contains appreciable amount of insoluble fibre. Ensminger and Ensminger reported that one cup of cooked lima bean gives $65.8 \%$ of the daily fibre value (17). The carbohydrate values were high and comparable. It ranged from $65.60 \%$ to $71.51 \%$. It was reported that the carbohydrate content of beans ranged from 55.6 to $73.2 \%$ depending on the variety $(18,19)$.

Table 2. Proximate Composition of Seven Varieties of Raw Lima Bean Seeds (Dry Weight Basis)

\begin{tabular}{lllll}
\hline Sample & Protein\% & Fat \% & Ash\% & Fibre \% \\
\hline GBRV & $24.33 \pm 0.06$ & $1.08 \pm 0.01$ & $3.83 \pm 0.02$ & $4.38 \pm 0.05$ \\
MBRV & $21.48 \pm 0.02$ & $0.094 \pm 0.00$ & $4.13 \pm 0.05$ & $4.43 \pm 0.05$ \\
DBRV & $20.45 \pm 0.03$ & $1.12 \pm 0.02$ & $3.93 \pm 0.02$ & $4.28 \pm 0.03$ \\
DCV & $25.43 \pm 0.08$ & $0.96 \pm 0.00$ & $3.85 \pm 0.01$ & $4.16 \pm 0.03$ \\
DRV & $23.55 \pm 0.06$ & $1.06 \pm 0.01$ & $4.08 \pm 0.05$ & $3.99 \pm 0.03$ \\
BKV & $20.56 \pm 0.031$ & $1.15 \pm 0.03$ & $4.12 \pm 0.01$ & $4.22 \pm 0.01$ \\
MBKV & $19.33 \pm 0.03$ & $0.98 \pm 0.00$ & $3.88 \pm 0.01$ & $6.03 \pm 0.21$ \\
\hline
\end{tabular}

Mean \pm SD of Three Determinations, GBRV = Golden brown variety, MBRV = Mottled brown variety, DBRV = Dark brown variety, DCV $=$ Deep cream variety, $\mathrm{DRV}=$ Dark red variety,BKV $=$ Black Variety, $\mathrm{MBKV}=$ Mottled black variety

The mineral composition of the lima bean varieties were presented in table 3 . The zinc content of all the samples were high and comparable. It ranged from 28.88 to $33.06 \mathrm{mg}$, indicating that they are rich sources of zinc. The 
iron, copper and phosphorus values of all the varieties were also high and comparable. There were variations in the iron content in all the samples. The iron values ranged from 57.22 to $60.24 \mathrm{mg}$. The MBRV, DCV and MBKV had similar $\mathrm{Fe}$ values value $(60.24,60.22$ and $60.02 \mathrm{mg}$, respectively). The copper content of the samples ranged from 4.38 to $4.68 \mathrm{mg}$. The GBRV had the highest $\mathrm{Cu}$ value
(4.68) mg among all the varieties, while the DBRV has the least $4.38 \mathrm{mg}$. The phosphorus level ranged from 4.20 to 4.66mg. The DCV had the highest phosphorus value (4.66mg) followed by the MBKV that had 4.61mg. Apata and Ologhobo (20) reported similar findings. Lima beans are rich sources of these minerals $-\mathrm{Fe}, \mathrm{Zn}, \mathrm{Cu}$, and $\mathrm{P},(21)$.

Table 3. Mineral Composition of Seven Varieties of Raw Lima Bean Seeds (mg/100g)

\begin{tabular}{lllll}
\hline Sample & Zinc $(\mathbf{Z n})$ & Copper $(\mathbf{C u})$ & Iron (Fe) & Phosphorus (P) \\
\hline GBRV & $30.08 \pm 0.02$ & $4.68 \pm 0.06$ & $57.22 \pm 0.08$ & $4.43 \pm 0.08$ \\
MBRV & $28.88 \pm 0.01$ & $4.56 \pm 0.06$ & $60.02 \pm 0.08$ & $4.20 \pm 0.06$ \\
DBRV & $31.45 \pm 0.02$ & $4.38 \pm 0.02$ & $56.56 \pm 0.07$ & $4.52 \pm 0.06$ \\
DCV & $28.93 \pm 0.04$ & $4.53 \pm 0.02$ & $60.24 \pm 0.09$ & $4.66 \pm 0.04$ \\
DRV & $33.06 \pm 0.06$ & $4.45 \pm 0.01$ & $59.33 \pm 0.07$ & $4.48 \pm 0.04$ \\
BKV & $31.44 \pm 0.08$ & $4.50 \pm 0.00$ & $55.25 \pm 0.07$ & $4.57 \pm 0.06$ \\
MBKV & $30.28 \pm 0.06$ & $4.53 \pm 0.01$ & $60.22 \pm 0.09$ & $4.61 \pm 0.06$ \\
\hline
\end{tabular}

Mean \pm SD of Three Determinations, GBRV $=$ Golden brown variety, MBRV $=$ Mottled brown variety, DBRV $=$ Dark brown variety, DCV $=$ Deep cream variety, DRV = Dark red variety, BKV =Black Variety, MBKV =Mottled black variety

The anti-nutrient and food toxicant content of the lima bean varieties were shown in table 4 . The tannin levels ranged from 0.16 to $0.50 \mathrm{mg}$. The black variety had the higher tannin value $(0.50 \mathrm{mg})$ among all the varieties, followed by the dark red (DRV) and dark brown (DBRV) varieties. It is known that the darker the colour of a seed the higher the tannin levels (22). The presences of relatively high levels of phytate and trypsin inhibitor in all the varieties were not surprising. Legumes are known to contain a lot antinutritional factors which lower the digestibility of legume proteins and decrease the absorption of divalent metal ions in the intestine (23).

There were slight variations in the hydrogen cyanide content of the samples. It ranged from 38.38 to $43.55 \mathrm{mg}$.
The black variety had the highest $\mathrm{HCN}$ value $(43.55 \mathrm{mg})$. This high and comparable HCN values for all the varieties indicated that lima bean contains much quantity of this food toxicant which has deleterious effect when consumed raw or improperly processed. This observation was similar to the reports in literature $(24,25)$, they noted that lima bean has the highest content of HCN (10-312mg/100g, 420 $\mathrm{mg} / \mathrm{kg}$ ) depending on the variety, when compared with other legumes. According to Manay and Sharaswamy, a cyanide content in the range of $10-20 \mathrm{mg}$ per $100 \mathrm{~g}$ of pulse is considered safe. They noted that many legumes, except lima bean (Phaseolus lunatus) contain cyanide within this $\operatorname{limit}(25)$.

Table 4. The Antinutrient and Food Toxicant Contents of Raw Seven Lima Bean Varieties (Mg/100g)

\begin{tabular}{lllll}
\hline Sample & Tannin & Phytate & Trypsin Inhibitor \\
\hline GBRV & $0.16 \pm 0.00$ & $20.33 \pm 0.02$ & $26.48 \pm 0.04$ & HCN \\
MBRV & $0.18 \pm 0.01$ & $26.48 \pm 0.02$ & $27.33 \pm 0.06$ & $41.55 \pm 0.06$ \\
DBRV & $0.21 \pm 0.01$ & $23.14 \pm 0.02$ & $30.01 \pm 0.07$ & $38.38 \pm 0.02$ \\
DCV & $0.16 \pm 0.00$ & $20.56 \pm 0.01$ & $29.22 \pm 0.07$ & $40.61 \pm 0.04$ \\
DRV & $0.25 \pm 0.01$ & $18.26 \pm 0.00$ & $24.15 \pm 0.02$ & $42.06 \pm 0.04$ \\
BKV & $0.50 \pm 0.03$ & $21.56 \pm 0.01$ & $25.66 \pm 0.04$ & $41.48 \pm 0.2$ \\
MBKV & $0.18 \pm 0.01$ & $20.42 \pm 0.01$ & $24.56 \pm 0.01$ & $43.55 \pm 0.03$ \\
\hline
\end{tabular}

Mean \pm SD of Three Determinations, GBRV $=$ Golden brown variety, MBRV $=$ Mottled brown variety, DBRV $=$ Dark brown variety, DCV $=$ Deep cream variety, DRV $=$ Dark red variety, BKV =Black Variety, MBKV =Mottled black variety

The functional properties, (water absorption capacity, oil absorption capacity, foam capacity and least gelation concentration) were presented in table 5. The water absorption capacity of the samples varied. It ranged from 63.21 to 70.33 . The dark red variety (DRV) had the highest value for water absorption capacity (70.30). The high WAC value in all the varieties indicated that they have the ability of absorbing more water during cooking or processing. This high water absorption capacity indicated that seed flours will be good in baking industries. The low and comparable oil absorption capacity observed in all the varieties (1.20 to 1.30) suggested that their flours will not absorb oil, when they are used in akara production or in preparation of other fried foods. The foam capacity values ranged from 12.08 to 13.18. The dark red variety (DRV) and the mottled brown varieties (MBRV) had the highest value for foam capacity (13.18 and 13.02, respectively). The high foam capacity found in all the varieties indicated that they have good protein quality. Onimawo and Akubor reported that foam formation and foam stability are functions of protein type. They noted that protein foams are important in many processes in the beverage and food industries. Since foams are used to improve texture, consistency and appearance of foods (11).

The least gelation concentration ranged from 14-16. The GBRV, DCVB, BKV and MBKY had the same least 
gelation concentration value, while DRV and 'DBRV equally had similar values (14 and 15 , respectively). The mottled brown variety had the highest least gelation concentration value (16) among all the samples. The least gelation values found all the varieties were within the range (11).

Table 5. Functional Properties of The Lima Bean Varieties

\begin{tabular}{lllll}
\hline Sample & WAC $(\mathbf{g} / \mathbf{g})$ & OAC $(\mathbf{g} / \mathbf{g})$ & FC (\%) & LGC (\%) \\
\hline GBRV & $63.56 \pm 0.04$ & $1.30 \pm 0.01$ & $12.33 \pm 0.03$ \\
MBRV & $70.02 \pm 0.05$ & $1.28 \pm 0.01$ & $13.02 \pm 0.02$ & 14 \\
DBRV & $68.42 \pm 0.05$ & $1.24 \pm 0.02$ & $12.25 \pm 0.01$ & 16 \\
DCV & $63.21 \pm 0.04$ & $1.35 \pm 0.04$ & $13.18 \pm 0.01$ & 15 \\
DRV & $70.33 \pm 0.06$ & $1.23 \pm 0.01$ & $12.63 \pm 0.01$ \\
BKV & $69.02 \pm 0.06$ & $1.25 \pm 0.01$ & $12.08 \pm 0.01$ \\
MBKV & $67.44 \pm 0.03$ & $1.20 \pm 0.01$ & 15 \\
\hline
\end{tabular}

Mean \pm SD of Three Determinations, GBRV $=$ Golden brown variety, MBRV $=$ Mottled brown variety, DBRV $=$ Dark brown variety, DCV $=$ Deep cream variety, DRV $=$ Dark red variety, BKV $=$ Black Variety, MBKV =Mottled black variety, WAC=Water Absorption Capacity, OAC=Oil Absorption Capacity, $\mathrm{FC}=$ Foam Capacity, $\mathrm{LGC}=$ Least Gelation Concentration

\section{Conclusion}

Based on the result of this study, lima bean has a high nutrient profile despite the variety. Therefore, its cultivation and utilization should be promoted. However, because of its high toxic components $(\mathrm{HCN})$ which can precipitate deleterious effects in man and animal, lima bean should not be consumed raw or without adequate processing.

\section{References}

[1] FAO (1987) Promoting Under-exploited Food Plants in Africa: A brief for policy maker FAO press Rome, Italy.

[2] Kee E, Glancey J and Wooster T (1997) the Lima Bean:A Vegetable Crop for Processing. Hort tech.Vol 7 No. 2.

[3] A O A C (1985) Official Methods of Analysis Association of Official Analytical Chemists, Washington, D.C.

[4] Polacchi, W (1985) Food Composition Tables: Recommended Method for Deriving Nutrient Values in their Preparation J. Am Diet. Assoc. 85: 1134-1136.

[5] Ranjiham, S. K and Gopal, K (1980) Wet Chemical Digestion of Biological Materials for Mineral Analysis: in Laboratory Manual for Nutrition Research. Vikas, Pub. House, PVT Ltd, New Delhi India.

[6] Price, M. L and Butter, L.G (1977) Rapid Visual Estimation and Spectrophotometer Determination of Tannin Contents of Sorghum grain. J. Agric. Ltd. Chern 25; 1268-1270.

[7] Iatta, M and Eskin, M (1980) A simple and Rapid Colorimetric method for phytate Determination. J. Agric Fd. Chem29: 1315-1317.

[8] Hamerstrand, G. E., Black, T.T and Glover, J.D (1981) Trypsin inhibitors in soy Products; modification of standard Analytical Procedure. Cereal Chern. 58;42-43.

[9] Cooke R.D (1978) Anenzymatic Assay for the Cyanide Content of Cassava (Maniihot Escalanta) J.SC. Fd. Agric;29;345-352.

[10] Odo, F.O and Ishiwu, C. N (1999) Experimental Procedures for Food Water Analysis IMT Press, Enugu, Nigeria.
[11] Onirnawo, LA and Akubor, P.I (2005) Food Chemistry. Ambik Press Ltd. Benin City, Nigeria.

[12] Obi, 1. U (1986) Statistical Methods for Detecting Differences. Between Treatments Means SNAPP Press Nig. Ltd Enugu.

[13] Ene-Obong, R.N and Carnovale, E (1992) A Comparison of the Proximate, Mineral, and Amno acid Composition of Some Known and Lesser Known legumes in Nigeria. Fd. Chern. 43: 169-175.

[14] Aleter, V.A and Aladetimi, 0.0 (1989) Compositional Evaluation of some Underutilized edible Legume in Nigeria. Die N ahring 33: 1 009-1 016.

[15] Chikwendu, IN. (2005) Production and availability of ground. Bean, (Kerstingella Geocarpa) in a Typical Nigeria Community. Implication for Nutrition Education and National Development J. Home Econ res. 6 (1):135-141.

[16] Nwokolo, E (1987) A Nutritional Assessment of African yam Bean (Sphenostylis Stenocara) and Bambara Groundnut (Voantzeia Subterranea). J. Sci. Fd. Agric 41:123-129.

[17] Ensminger, A. R and Ensminger, M. K (1986) Food for Health: A Nutrition Encyclopedia. Clovis pegus Press, PP 19-21.

[18] NAS (1979) Tropical legumes: Resources for the future. National Academy of Science, Washington, DC USAPP 331.

[19] Apata, D.F and Ologhobo, A.D (1994) Biochemical Evaluation of Some Nigerian legume seeds. Fd. Chern 49:333-338.

[20] Kee, E, Glancey, J and Wooten T (1998) Successful Lima bean. Production in Delaware Cooperative Extensive Service, Extension Bulletin 137.

[21] Beebee, S. Gonzalez, A.V and Rengifo, J (2000) Research on Trace elements in the common bean. Fd. Nutr. Bull. 21; 381-39.

[22] Silano, V. Bansul, H.Cand Bozzini, A (1982) Improvement of Nutritional Quality of Food Crops. FAO Plant Production and Protection Paper 34, F AO Press, Rome, Italy.

[23] Ologho, A D, Fietuga, R.L and Tewe, 0.0 (1984) The Cyanogenic Glycoside Content of Raw and Processed Lima Bean Varieties. Fd Chern 13:117-128. 
[24] Okoli, N.P and Ugochukwu, E.N (1988) Cyanide contents of some Nigeria legumes and the effects of simple processing. Fd, Chern. 32:209-216.
[25] Manay, N.S and Sharaswamy M.S (2008) Food facts and Principles. New Age int. Ltd. New Delhi India. 